\title{
The welfare of amil zakat in Dompet Dhuafa, Central Java
}

\author{
Zummi Asma Diana ${ }^{1}$ \\ ${ }^{1}$ Universitas Islam Negeri Walisongo, Semarang, Indonesia
}

\begin{abstract}
Purpose - The purpose of this study is to examine the welfare level of amil zakat in Dompet Dhuafa. The salary received by one amil with another amil is different. Some fulfill the UMR of Semarang City, but there are also those that are still below the UMR of Semarang City.

Method - This study is performed using qualitative phenomenology analysis.

Result - The results of this study indicate that the welfare level of amil zakat in Dompet Dhuafa in Central Java using measurements according to BKKBN has included prosperity, starting from Prosperous Family II (KS II) to Prosperous Family III Pus (KS III Plus), and if using measurements according to BPS (Central Bureau of Statistics) shows that all amil zakat have lived properly and by the Prosperous Family according to BPS.

Implication - This study is expected to be able to give a picture of the stakeholders about the importance of minding the welfare of amil zakat.
\end{abstract}

Originality-This study is researching salary and wage effects on welfare with a qualitative approach. Previous existing researches are dominated by quantitative research.

Keywords: $\quad$ welfare; amil; Dompet Dhuafa; wage; phenomenology.

\footnotetext{
${ }^{1}$ Author correspondence: Zummi Asma Diana, zummi.asma@gmail.com, Universitas Islam Negeri Walisongo, Jl. Walisongo No.3-5, Tambakaji, Kec. Ngaliyan, Kota Semarang, Jawa Tengah 50185, Indonesia
} 


\section{Introduction}

Dompet Dhuafa is a non-profit organization, which aims to raise the dignity and social dignity of poor people through zakat, infaq, sadaqah, waqf,

JIEMB | 30 and other humanitarian funds. Born from the Republika journalist community, who often interacts with the poor and always meets the rich. Dompet Dhuafa has 12 branches in Indonesia and five overseas offices, one of which is located in Central Java Province.

The Muslim population in Central Java reaches $34,235,239$ people. So the zakat funds that can be extracted are quite large. According to the Chairman of the Central Java Province BAZNAS in the event "The Declaration of Zakat Conscious Movement of Central Java Province" in Grhadika Building Wednesday, January 24, 2018, that the potential of zakat in Central Java can approach 1 Trillion.

Management of zakat collectively becomes an independent socioeconomic movement and, in the hands of amil that is transparent and professional, becomes strategic in the context of increasing the effectiveness of zakat as a socio-economic institution. If zakat is not managed through amil, then the urgency of the benefits will be deemed lacking and will be exhausted for a moment. So that zakat funds cannot help empower education, health, and the economy.

According to Sahal Mahfud in the professional management of zakat requires skilled personnel, mastering problems related to zakat, full of dedication, honesty, and trustworthy. By religious instructions, trustworthiness must be carried out to ensure the achievement of its objectives with expertise and skills, especially administrative expertise.

The zakat officer known as amil or in the plural (popular) is 'amiliin' or 'amala.' Sometimes they are also referred to as al-sunnah and al-rok. Amil Zakat is a profession that is recognized in the Qur'an in the At-Taubah (9) verse 60:

"Zakah expenditures are only for the poor and for the needy and for those employed to collect (zakah) and for bringing hearts together (for Islam) and 
for freeing captives (or slaves) and for those in debt and for the cause of Allah and for the (stranded) traveler - an obligation (imposed) by Allah. And Allah is Knowing and Wise".

Amil Zakat is a profession, so an amil zakat must have a professional soul. The form of professionalism is to work full time, so it does not make the task JIEMB | 31 of managing zakat as activity number two. With his professionalism, an amil must be properly paid, so that he can devote all his potential to managing zakat funds properly. Amil zakat is in line with other professions in the professional work environment. The amil recruitment process is carried out through selection, just like the rigorous selection process of other professions.

Optimization of the zakat system as one of the processes of income redistribution, the position of amil in the eight asnaf groups has an extraordinary role, although it is unique. The zakat system will have a lot of dependence on mail's professionalism. The higher the level of amil professionalism, the higher the level of welfare of the mustahik, especially amil, bearing in mind the concept of fiqh clearly states that their rights are $12.5 \%$ or $1 / 8$ of the collected assets.

According to Bung Hatta, welfare is a feeling of life that is one level higher than happiness. People feel prosperous when they feel happy, no less what is within the limits that may be achieved, their souls are calmly born and mind nurtured, he feels justice in his life, he is free from torture poverty and the danger of poverty that threatens.

Based on the results of preliminary research conducted by researchers, about the meaning of welfare and the welfare level of amil zakat in Dompet Dhuafa, Central Java. Prosperity, according to Amil, is the fulfillment of material and spiritual needs, choosing to work in Dompet Dhuafa. One of the reasons is wanting to prosper in spiritual matters so that his worship becomes more diligent and organized.

One informant who has worked for one year and nine months in Dompet Dhuafa, Central Java, said that working in Dompet Dhuafa was aimed at earning money. Get a salary of one million nine hundred thousand rupiahs per 
month cannot meet the needs of the family, because they have to support their wife and two children. Selling online is a solution to meet their daily needs, while his wife works as a food seller who earns around Rp. 400,000 per month.

The salary received is still below the Semarang City minimum wage of Rp. 2,310,087.50 (two million three hundred ten thousand eighty-seven point fifty rupiahs). But there are some informants who have received salaries exceeding the Regional Minimum Wage (UMR) of Semarang City, which is Rp. 2,400,000 per month. However, the cost of the needs of each amil is different; some can set aside their salary, while others cannot set aside their salary because they are used up for family needs.

The difference in the acquisition of amil salaries in the Dompet Dhuafa environment does not make the spirit of the amil decrease in managing zakat funds. However, the increase in amil salaries every year increases the enthusiasm and motivation for some amil in managing the institution, so that his life will be more secure and peaceful because the needs can be met.

With this, the researcher wants to know the level of welfare received by amil zakat while working in Dompet Dhuafa. So that researchers want to research with the title Welfare Amil Zakat in Dompet Dhuafa, Central Java. Based on the background that has been submitted then the following research problem formulation was made, What is the welfare level of amil zakat in Dompet Dhuafa, Central Java?

\section{Literature review}

The study discussed in this study will focus on the welfare of amil zakat, to find out broadly the theme of the researchers collecting works, including:

Istianah Ni'mah (2016), "Analysis of Outsourcing Employee Welfare in the Perspective of PT Spirit Krida Indonesia Employees." The results showed that the dimensions of employee welfare at PT Spirit Krida Indonesia in the employee perspective, include: First, dhoruriyat is a salary according to the needs of decent living (KHL). Second, hajiyyat, such as training/education, 
health insurance (BPJS), work permit due to illness and administrative assistance applying for a loan. Third, tahsiniyyat, such as death compensation and love money, work clothes, mosque and canteen, incentives, and holidays.

Among the three dimensions, welfare based on the concept of dhoruriyyat is the most dominant salary. But according to the author's dhorurriyat needs are only met for employees who are still single, while for employees who are married, these needs have not been fulfilled but are still burdened by salary cuts that should not be done by the company.

The research that I do is different from most of the existing research, from some of the results of the above research using a type of quantitative research that looks at a salary or wage effect on welfare obtained by employees.

While the research did was using qualitative research, by directly looking at the phenomena that exist and conducting interviews directly with the amil (zakat manager) in Dompet Dhuafa, Central Java. To know the level of welfare that has been obtained by the amil zakat while working in Dompet Dhuafa, Central Java.

\section{Research methods}

This research is descriptive qualitative research. Qualitative research is a research method that aims to describe a social reality that emphasizes the importance of individual subjective experiences in creating a social world and emphasizes cases that are unique to the individual. Qualitative research intends to understand the phenomena experienced by research subjects such as behaviors, perceptions, motivations, actions and so on which are described descriptively in the form of words in a specific context that utilizes various scientific methods.

The approach to be used is to use a sociological and psychological approach that is used to investigate, discover, describe, and explain the quality or features of social influence so that it can be explained, measured or depicted that is concerned with the quality of data by investigating a social phenomenon and problems of human life, and emphasizing the nature of 
socially constructed reality, the close relationship between the researcher and the subject under study.

The social approach is the community with its institutions, groups with JIEMB | 34 various activities. Concretely, this approach discusses aspects or components of human culture, for example, family, traditions, customs, morality, social norms, and so on.

Qualitative research methods using psychological science approaches namely research methods that describe the object of research through procedures and data that are non-specific to psychological objects, such as verbal data, analytical techniques, descriptive qualitative, thematic analysis techniques, and phenomenological analysis techniques to express objects of psychological phenomena. This method is based more on the process of verstehen (appreciation from within) rather than erklaeren (explanation from outside).

Field research was carried out in Dompet Dhuafa, Central Java, researchers wanted to see the level of welfare obtained by amil zakat in Dompet Dhuafa, Central Java. The qualitative research method was chosen because the researcher wanted to get a description of the welfare level of amil zakat in Dompet Dhuafa, Semarang.

\section{Results and discussion}

Welfare comes from the word "prosper." Prosperity comes from the Sanskrit language, which contains the meaning of "catera" which means umbrella. Welfare contained in the meaning of "catera" (umbrella) is a prosperous person, a person who in his life is free from poverty, ignorance, fear, or worry so that his life becomes safe, peaceful, both physically and mentally.

Welfare according to Islamic sharia demands the fulfillment of material and spiritual aspects in a balanced way. Islam has a goal to realize the benefit of mankind, both in the world and the hereafter. The essence of family welfare 
and happiness in Islam lies not only in the amount of material, but the extent to which the family is maintained in the faith and devotion to Allah SWT.

The measurement of welfare, according to Islam, has an indicator of welfare, which is the goal of sharia. According to Chapra (2001), faith is the most important thing in welfare development, because faith has a significant impact on the nature, quantity, and quality of material and psychological needs. Faith makes a balance between material and spiritual encouragement in humans, building individual peace of mind, and increasing family and social solidarity.

An organization or institution has an employee maintenance program, one of which is payroll administration. Payroll administration is the process of activities to carry out payroll. Talking about payroll, it is necessary to have a kind and basis for determining income related to work done by employees/employees.

The government has made efforts to improve the welfare of employees by increasing the minimum wage based on the necessities of decent living and attention to economic productivity growth. The stages of achieving the necessities of a decent life are regulated in a Ministerial Decree.

The minimum wage consists of the minimum wage based on the province or district/city and the minimum wage based on the sector in the province or district/city. The minimum wage is determined by the Governor by taking into account recommendations from the Provincial Wage Board and the Regent / Mayor.

Nationally there are two versions of the measurement of family welfare, namely the measurement of welfare carried out by the BKKBN (National Population and Family Planning Agency) and BPS (Central Statistics Agency).

\section{Based on BKKBN (National Population and Family Planning Agency)}

Indicators of the family welfare level of the BKKBN (National Population and Family Planning Board) are as follows: 
1. Pre-prosperous family (often classified as "very poor"), i.e. families that do not meet one of the 6 Prosperous Family I (KS I) indicators or "basic needs" indicators.:

a. In general, family members eat two times a day or more.

b. Family members have different clothes at home/work / go.

c. The house occupied has a roof and floor.

d. If a sick family member is taken to a health facility.

e. Couples of childbearing age if they want to go on family planning go to the contraception service facilities.

f. All children aged 7-15 in the family go to school.

2. Prosperous family II (KS II)

Families that can meet all the indicators in KS I and can meet all the KS II indicators which include:

a. In general, family members carry out religious worship.

b. At least once a week, family members eat side dishes of meat/fish/eggs.

c. All family members get at least one new set of clothes in a year.

d. The floor area of at least eight meters square for each occupant.

e. The last three months of family members in good health.

f. One or more family members work to earn a living.

g. Family members aged 10-60 years can read Latin writing.

h. Women of childbearing age with two children are currently using birth control.

3. Prosperous family III (KS III)

Families that have been able to meet all KS I and KS II indicators and can meet all KS II indicators which include:

a. Families try to increase their religious knowledge. 
b. Some family income is saved in the form of money and goods.

c. Families eat together at least once a day to be able to communicate.

d. Families often participate in community activities in the neighborhood.

e. Families get information from newspapers / TV / magazines / radio.

4. Prosperous family III plus (KS III Plus)

Families who have been able to meet all the indicators of KS I, KS II, KS III and can meet all the KS III Plus indicators which include:

a. Actively contributing material regularly.

b. As a manager of social organizations.

\section{Based on BPS (Central Bureau of Statistics)}

Indicators of the level of household welfare in a family, according to BPS include:

1. Household income is all income or receipts in the form of money or goods from all household members obtained in the form of wages or salaries, income from household businesses, and transfer receipts.

2. Consumption of home food is food that is consumed by household members regardless of their origin.

3. Living conditions are living conditions such as the condition of buildings, rooms, building materials used, and sanitation conditions.

4. Housing facilities are facilities available to support housing facilities such as drinking water, latrines, electricity, telephone and household furniture.

5. Health of household members is the health condition of household members in terms of frequent health problems, both chronic (chronic) diseases and other health problems that can interfere with their activities. 
6. The ease of obtaining health services from medical/paramedical personnel is the ease of being seen in economic and non-economic terms, such as medical costs, affordable, smooth handling, relatively close distances, and straightforward procedures.

7. The ease of entering children into educational levels, namely kindergarten, elementary school, junior high school, senior high school, and equivalent. In terms of school fees, the distance to school is relatively close, and the procedures for admitting new students and, most importantly, good quality education.

8. A sense of security from all the disturbances of crime such as robbery, robbery, and extortion.

9. Ease of accessing information and communication technology. To find out the latest information that is happening to gain a lot of knowledge.

Amil, according to Yusuf Qardhawi is those who carry out all the affairs of zakat, ranging from collectors to treasurers and guards, from the recorder to the counters which record the entry and exit of alms and distribute to the mustahik.

The requirements for an amil zakat are a Muslim, a mukallaf, honest, understanding the zakat law so that in carrying out their duties they do not make a lot of mistakes, can carry out their duties so that the management of zakat becomes optimal, some scholars' require that the manager of the zakat be male because of managing alms and an amil zakat must be free may not be a slave.

The purpose of the amil zakat profession is to fulfill responsibilities with the highest standards of professionalism and achieve the highest levels of performance. To achieve this goal, there are four basic needs that must be fulfilled by amil zakat, namely shiddiq/integrity, trustworthiness/credibility, tabligh/education, advocacy, and outreach, as well as fathanah/professionalism.

Law of the Republic of Indonesia Number 23 of 2011 concerning Management of Zakat also explains the rights of a zakat manager that. Amil 
rights are a certain part of zakat which can be utilized for operational costs in the management of zakat by Islamic law.

\section{The welfare level of Amil Zakat in Dompet Dhuafa, Central Java}

Researchers in analyzing this study will use three theories, namely: The level of welfare according to the BKKBN (National Population and Family Planning Agency) and the level of welfare according to BPS (Central Statistics Agency). So that it can produce several levels of welfare.

The level of welfare is based on the BKKBN (National Population and Family Planning Agency).

The results of research conducted based on interviews and observations obtained income levels is presented in Table 1. From Table 1 it can be seen that the welfare level of amil zakat in Dompet Dhuafa in Central Java based on the BKKBN Prosperous Family Indicator shows that, the level of Prosperous Family II is four informants (44.4\%) and the level of Prosperous Family III is four informants (44.4\%). Only one informant who has reached the level of Prosperous Family III Plus.

Informants who have reached Prosperous Family II (KS II), namely the Staff Program in the Field of Economics, Staff in the Social Field Program, CRM Staff, and OB Staff. Indicates that the family has been able to fulfill six indicators of KS I stages and $8 \mathrm{KS}$ II indicators but cannot meet one of the $5 \mathrm{KS}$ III indicators.

Informants who have reached Prosperous Family III (KS III) are Marketing Staff, Fundraising Coordinator, Program Coordinator, and Financial Coordinator. It shows that the family has been able to fulfill six indicators of the KS I stage, 8 KS II indicators and 5 KS III indicators, but does not meet one of the 2 Prosperous III Plus (KS III Plus) or "self-actualization" indicators.

Table .1 Informant welfare level based on BKKBN measurements

\begin{tabular}{llll}
\hline No & Welfare level & Informant & Percentage (\%) \\
\hline 1 & KS II & 4 & 44,4 \\
2 & KS III & 4 & 44,4 \\
3 & KS III Plus & 1 & 11,2 \\
Total & & 9 & 100 \\
\hline
\end{tabular}


While the informants who have reached Prosperous Family III Plus (KS III Plus) are Branch Managers, indicates that the family has been able to fulfill 6 KS I indicators, 8 KS II indicators, and 5 KS III indicators and 2 KS III Plus stage indicators.

Welfare level based on Central Bureau of Statistics (Badan Pusat Statistik; BPS)

Aspects that will be used as a measurement of the welfare level of amil zakat, one of which is an indicator of welfare according to BPS, among others:

1. Income

The income/salary obtained by the informant is less than Rp. 2,000,000 there was one informant with an MA education background (Madrasah Aliyah), which was more than Rp. 2,000,000 there were five informants with a bachelor's degree and one year of service. Whereas more than Rp. $3,000,000$ there are three informants who have a Bachelor's education background and a work period of more than three years and have a high position in the institution. From the results, there are that the level of income/salary of the informant is almost reaching and has reached the Minimum Wage of Semarang, which is Rp. 2,310,087.50.

\section{Expense}

The expenditure of informants' needs is relatively low Rp.700,000 because they live in Semarang City and do not yet have family dependents. There are four informants whose expenditures are more than Rp. 1,000,000 because they live outside the city of Semarang, so they have to pay to board. While informants whose expenses are more than Rp. 2,000,000 there are four informants who are all married, so they have dependents to support their families. So the informant's income from the salary that has been received does not exceed the expenses used to meet the needs of each month.

3. State of residence

Based on observations made by researchers that the floor area of the informants have all been more than eight meters square. 
4. Facility of residence

One measure of the comfort of a residence is an adequate living facility. The lighting sources in the house or the amam residence are all from electricity. While the source of springs comes from PAM (Drinking Water Company), wells and springs. Some bathrooms use a public bathroom for all families, and there are also those who use a private bathroom in the room. While the fuel used by all informants is LPG.

5. Health

The health of the informant's family members is almost all healthy, but there are only a few members who experience illness due to uncertain weather conditions and frequent rain.

6. Ease of utilization of health worker facilities

The ease of availability of health workforce facilities is supported by the existence of facilities from institutions in the form of Health BPJS given to each informant so if sick BPJS Health can be used to ease the cost of treatment.

7. Quality of education

The informant is almost all of his last education S-1 (undergraduate). So the informant can already be said to have broad insight and sufficient knowledge to be able to manage the institution so that it is increasingly developed and optimal.

8. Ease of sending children for education

The informant who has school children is only one informant, aged 4.5 years, and has just entered PAUD (Early Childhood Education), which is located about 200 meters from the informant's house, entered three times a week, namely Tuesday, Thursday and Saturday. Most of the informants of their houses are close to educational facilities starting at PAUD (Early Childhood Education), kindergarten (kindergarten), elementary school (elementary school), junior high school (junior high school) and high school (senior high school). The longest distance is about 2 kilometers. 
9. Feeling safe upon criminal

The Dompet Dhuafa Central Java office operates until 17:00 WIB, so it is still relatively safe for informants to travel to their respective homes. When at home, security is guaranteed, because there is a lot of lighting so it will be far from a crime.

10. Ease to access information technology and communication

Provided computer and internet network facilities at the Dompet Dhuafa office in Central Java. Each informant has a cellphone that can be used to access the internet and communicate with fellow friends and family.

\section{Conclusion}

After the author explain and analyze the welfare level of amil zakat in Dompet Dhuafa, Central Java, the authors conclude below. Amil welfare level using measurements according to BKKBN and BPS:

1. The level of welfare measurement, according to BKKBN, gets the result that, regarding the welfare of Amil in Dompet Dhuafa, Central Java, it has reached the level of Prosperous Family II, Prosperous Family III, and Prosperous Family III Plus.

2. The level of measurement of family welfare, according to BPS, gets the result that it can already be said to reach the level of a prosperous family because in terms of income and expenditure are balanced even there are some amil who regularly save every month.

\section{References}

Abbas, Anwar, Bung Hatta dan Ekonomi Islam, Jakarta : PT. Kompas Media Nusantara, 2010.

Ahmadi, Abu, Sosiologi Pendidikan, Surabaya: PT Bina Ilmu, 1982.

Badan Pusat Statistik. Statistik Kesejahteraan Rumah Tangga. Jakarta : Badan Pusat Statistik, 2016. 
The welfare of amil zakat in Dompet Dhuafa...

Bungin, Burhan, Penelitian Kualitatif, Jakarta : Prenada Media Group, edisi kedua, 2011.

Metode Penelitian Sosial \& Ekonomi : Format-format Kuantitatif dan Kualitatitf, Jakarta : Prenada Media Group, 2007.

Chapra, Umar M, Masa Depan Ilmu Ekonomi Sebuah Tinjauan Islam, Jakarta : Gema Insani Press, 2001.

Departemen Agama RI, Al-Qur'an dan Terjemah, Bandung : CV Penerbit Diponegoro, Cet. 10, 2006.

Edison, Emon, Pengembangan Sumber Daya Manusia, Bandung: Penerbit Alfabeta, Cetakan kedua, 2010.

Fahrudin, Adi, Pengantar Kesejahteraan Sosial", Bandung : PT. Refika Aditama, Cet kedua, 2014.

Fahwah, Aliyah, "Faktor Sosial Terhadap Kesejahteraan Islami Keluarga Muslim di Kota Surabaya", Jurnal Ekonomi dan Bisnis, Tahun XXIII, No. 2 Agustus 2013.

Forum Zakat, Cetak Biru Pengembangan Zakat Indonesia 2011-2025 Panduan Masa Depan Zakat Indonesia, Jakarta: Forum Zakat (FOZ), 2012.

Hafidhuddin, Didin, Manajemen Zakat Indonesia, Jakarta : Forum Zakat (FOZ), 2012

Hanurawan, Fattah, Metode Penelitian Kualitatif Untuk Ilmu Psikologi, Jakarta: PT. RajaGrafindo Persada, 2016.

Hardiyansyah, Haris, Metodologi Penelitian Kualitatif untuk IImu-ilmu Sosial, Jakarta: Salemba Humanika, 2010

Hasan, Muhammad, Manajemen Zakat Model Pengelolaan Yang Efektif, Yogyakarta : Idea Press, 2011.

Kementerian Agama RI, Panduan Organisasi Pengelola Zakat, Jakarta : CV. Refa Bumat Indonesia, 2013.

Keputusan Gubernur Jawa Tengah Nomor 560/94 Tahun 2017, Upah Minimum Pada 35 (tiga puluh lima) Kabupaten/Kota di Provinsi Jawa Tengah Tahun 2018.

Laela, Sugiyarti Fatma, "Analisis Faktor-Faktor Yang Mempengaruhi Kinerja Organisasi Pengelola Zakat", TAZKIA Islamic Finance \& Business Review, Vol. 5, No. 2 Agustus-Desember, 2010. 
Nasir, Moh, Metode Penelitian, Bogor: Ghalia Indonesia, 2005.

Ni'mah, Istianah, "Analisis Kesejahteraan Karyawan Outsourcing Dalam Perspektif Karyawan PT Spirit Krida Indonesia". Equilibrium: Jurnal Ekonomi Syariah, Volume 4 Nomor 2, 2016.

Mahfudz, Sahal, Nuansa Fiqih Sosial, Yogyakarta: LKiS, 1994.

Moelong, Lexy J., Metodologi Penelitian Kualitaif, Bandung: PT.RemajaRosdakarya, Cet. 31, 2013.

Mufraini, Arief, Akuntansi dan Manajemen Zakat Mengkomunikasikan Kesadaran dan Membangun Jaringan, Jakarta : Kencana Prenada Media Group, Cetakan ke-3, 2012.

Qardawi, Yusuf, Fiqh Zakat, Maktabah Wahibah, Juz 2, 1945.

Ramadhany, Maria dkk, "Pengaruh Program Kesejahteraan Karyawan Terhadap Semangat Kerja Karyawan Dan Prestasi Kerja Karyawan (Studi Pada Karyawan Tetap Kompartemen SDM PT. Petrokimia Gresik)". Jurnal IImiah, Fakultas IImu Administrasi Universitas Brawijaya.

Sugiyono, Memahami Penelitian Kualitatif, Bandung : Alfa Beta, Cetakan keVIII, 2013.

----------, Statistika untuk Penelitian, Bandung: Alfabeta, cet. Ke-23, 2013.

Tanjung, Hendri dan Abrista Devi, Metode Penelitian Ekonomi Islam, Jakarta: Gramata Publishing, 2013

Wardhana, Anak Agung Adhy, "Sistem Pengendalian Manajemen Pada Organisasi Nirlaba", Makalah : Mata Kuliah Managemen Control System : Program Studi Magister Manajemen Fakultas Ekonomika dan Bisnis Universitas Gajah Mada, 2014.

Wawancara dengan amil zakat di Dompet Dhuafa Jawa Tengah, 19 Desember 2018

Undang-Undang Nomor 23 Tahun 2011, Pengelolaan Zakat, Pasal 1, ayat (11). http://aplikasi.bkkbn.go.id/mdk/BatasanMDK.aspx diakses pada tanggal 19 Februari 2018

https://www.dompetdhuafa.org/ diakses tanggal 09 Januari 2019 https://jateng.bps.go.id/statictable/2016/08/19/1272/jumlah-pendudukmenurut-kabupaten-kota-dan-agama-yang-dianut-di-provinsi-jawatengah-2015.html diakses tanggal 12 Januari 2019. 
The welfare of amil zakat in Dompet Dhuafa...

http://jateng.tribunnews.com/2018/01/24/potensi-dana-zakat-di-jawatengah-mencapai-rp-1-triliun-setahun?page $=2$ diakses tanggal 12 Januari 2019.

JIEMB | 45

Journal of Islamic Economics, Management, and Business - Vol. 1 No. 1 (2019) 